\title{
Mapping of nursing activities related to diagnosis: delayed growth and development
}

\author{
Mapeamento das atividades de Enfermagem relacionado ao diagnóstico: atraso no \\ crescimento e desenvolvimento
}

Evair Barreto da Silva ${ }^{1}$, Flávia Paula Magalhães Monteiro ${ }^{1}$, Sabrina Silva dos Santos ${ }^{1}$, Emanuella Silva Joventino ${ }^{1}$, Emília Soares Chaves Rouberte ${ }^{1}$

Objective: to map nursing activities related to the NANDA-I "delay in growth and development" diagnosis and to compare them with the activities recommended by the Nursing Intervention Classification. Methods: this is a quantitative study performed with primary care nurses. Professional identification variables and a list of defining characteristics of the diagnosis under study were collected for nurses to list nursing activities. Results: all participants were female, mean age of 42.2 years old, and 8.2 years of exercise in primary care. A total of 42 nursing activities were compared with four nursing interventions: 1) improvement of child development; 2) care for development; 3) developmental improvement: adolescent; 4) orientation to parents: raising children. Conclusion: most of the nursing activities developed by the participants correspond to those recommended by the Classification of Nursing Interventions.

Descriptors: Growth and Development; Child Health; Nursing.

Objetivo: mapear atividades de enfermagem relacionadas ao diagnóstico "atraso no crescimento e no desenvolvimento" da NANDA-I e compará-las com as atividades preconizadas pela Classificação de Intervenções em Enfermagem. Métodos: estudo quantitativo realizado com enfermeiros da Atenção Básica. Foram coletadas variáveis de identificação profissional e uma relação das características definidoras do diagnóstico em estudo para que os enfermeiros listassem as atividades de enfermagem. Resultados: todos os participantes eram do sexo feminino, com idade média de 42,2 anos, e de 8,2 anos de exercício na atenção básica. Listaram-se 42 atividades de enfermagem, as quais foram comparadas com quatro intervenções de enfermagem: 1) melhora do desenvolvimento infantil; 2) cuidados com o desenvolvimento; 3) melhora do desenvolvimento: adolescente; 4) orientação aos pais: educando os filhos. Conclusão: a maioria das atividades de enfermagem desenvolvida pelos participantes corresponde ao preconizado pela Classificação de Intervenções em Enfermagem.

Descritores: Crescimento e Desenvolvimento; Saúde da Criança; Enfermagem.

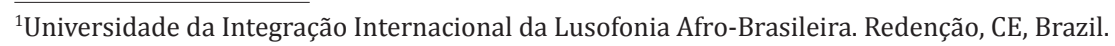

Corresponding author: Evair Barreto da Silva

Rua Ludugero Guilherme da Costa, 176. CEP: 62790-000. Redenção, CE, Brazil. E-mail: evairbarreto@bol.com.br 


\section{Introduction}

Child health care is a very importance activity due to vulnerability at this stage of the life cycle. It is expected to reduce the incidence of diseases through the monitoring of the child in childcare, promoting their health so they can grow and develop to reach their full potential ${ }^{(1)}$. Thus, it is imperative to raise possible interventions and nursing activities aimed at delaying growth and development to identify early problems and meet the main health needs of this people.

A study conducted by the National Family Health Survey in Indian cities between 2005 and 2006 found that at least $25.0 \%$ of children under five years old living in urban areas had growth retardation. This deficit, especially in developing countries, is related to more precarious socioeconomic conditions ${ }^{(2)}$.

Childhood growth is influenced by intrinsic (genetic) factors and extrinsic factors (feeding, health, hygiene and general care with the child), that is, related to the conditions in which the child is submitted. On the other hand, child development is a broad concept that involves learning and psychic and social aspects besides to physical growth ${ }^{(3)}$.

The child is a vulnerable human being and needs protection. Therefore, it is indispensable that the assistance to his health is systematic and in a continuous way, so it becomes possible the implementation of interventions of promotion and recovery of health and well-being, with the purpose of guaranteeing the healthy development and growth of children $^{(4)}$. However, it is worth mentioning that in adolescence and even into adulthood there is skills development, such as psychomotor, socio-affective, cognitive, among others.

In this sense, monitoring the growth and development of the individual provides support for the establishment of nursing diagnoses and the planning of the necessary care. Also, it contributes directly to the improvement of the quality of nursing care provided, to systematize care and to program the stages of the nursing process, a fact that can add value to the quality of life of these children ${ }^{(5)}$.

To this end, nurses have developed their care based on the nursing process. The Systematization of Nursing Care is a methodology of the organization, planning, and execution of actions performed by the team during the period in which the individual is under the nursing care. According to the Federal Nursing Council Resolution 358/2009, the Nursing Process consists of five stages: Nursing history, Nursing diagnosis, Nursing planning, implementation and Nursing evaluation ${ }^{(6)}$. This process represents the nurses' work tool with the purpose of identifying the patient's needs and presenting a proposal to their assistance and care, being able to direct the Nursing Team in the actions to be performed ${ }^{(7)}$.

According to NANDA International (NANDA-I), the diagnoses are part of a classification system that proposes the universalization of the problems found in the patients by the nurses, being defined by the clinical judgment of the individual, family or community responses to the actual or potential health problems. The components of nursing diagnosis include the label or title, definition, defining characteristics, related factors or organized risk factors in domains and classes ${ }^{(8-9)}$.

In association with the NANDA-I taxonomy, the Nursing Interventions Classification (NIC) is available. It is a standardized language system of nursing, with the purpose of communicating a common meaning to the different places of nursing, as well as assisting the improvement of the care and management practice through the development of research that allows the comparison and evaluation of nursing care provided in different settings. Thus, the Classification of Nursing Interventions includes the interventions that nurses perform with patients, being independent or collaborative, of direct and indirect care ${ }^{(10)}$.

Considering the importance of nursing actions for growth and development, this study aimed to map nursing activities related to the NANDA-I "delay in growth and development" diagnosis and to compare 
them with the activities recommended by the Classification Of Nursing Interventions.

\section{Methods}

This is a descriptive and comparative study carried out between July and November of 2016 with nurses who work in the primary care of the municipality of Redenção-CE, Brazil. The municipality counts on eleven nurses, so for the selection of the sample, the inclusion criterion was acting in the primary care of the municipality, and the exclusion criteria were nurses who were away from work on leave or who were on vacation during the data collection period. Thus, the sample reached in the study was nine nurses.

For the data collection, the interview method was used to an adapted form ${ }^{(11)}$, containing variables of the professional's identification and their academic trajectory, and all the defining characteristics of nursing diagnosis, growth retardation, and development. Next, to each defining characteristic, there was a table where nurses would list their nursing prescriptions. The defining characteristics of this diagnosis and found in the form were: blunt affection (difficulties in expressing emotions and feelings); Delay in performing skills typical of the age group; Altered physical growth; Inattention; Difficulties in performing skills typical of the age group; Inability to perform age-appropriate self-control activities; Inability to perform self-care activities appropriate to age and decreased reaction time.

The data collected were compiled in the Excel 2010 program and, later, the nursing activities/interventions prescribed by the nurses were analyzed and compared with the interventions proposed by the NIC, obtaining the mapping of nursing interventions/activities similar or different from those recommended by the Classification of Nursing Interventions ${ }^{(10)}$.

For the organization of these data, the methodology of mapping these activities was used ${ }^{(12)}$, describing the mapping of nursing diagnoses, considering the following aspects: to map the "meaning" of words, not just words; to use the "keyword" in the intervention to map the NIC intervention; to use the verbs as the "keywords" in the intervention; to map from the intervention label to the activity; to maintain consistency between the nurse's intervention and the NIC definition; to use the more specific intervention label; to map the verb "investigate" (activities) and "monitor" (intervention); to make a "Chart" for the activity "documentation"; the verb "teach" for the intervention/teaching activity when the main focus is on teaching; to map the verb "teach" to the specific intervention label when teaching is less intense or related to other activity in the general order/intervention; to map the verb "to order" for the intervention "supply management"; to map interventions that have two or more verbs for the two or more interventions in the corresponding $\mathrm{NIC}^{(10)}$.

In the cross-mapping, three phases were followed: identification of the nursing prescriptions related to the nursing diagnosis, delay in growth and development; cross-mapping of each nursing intervention/activity prescribed by nurses with the nursing activities described in the NIC; correspondence of each nursing activity mapped with the nursing interventions for the diagnosis delayed growth and development.

In the execution of the first phase, when registering prescribed nursing activities, in the case of similar and repeated activities, content normalization was performed with the exclusion of repetitions, spelling corrections, synonymy analysis, verbal tenses adequacy, gender uniformity and number and exclusion of pseudo-terminological expressions.

It should be emphasized that the nursing diagnosis with a title "delayed growth and development" is general, not specific only for the child population. Also, the NIC nursing interventions the nursing activities corresponded to this diagnosis involve the infantile people, but may also include, for example, the adolescents.

Descriptive statistics were used, with absolute 
and relative frequencies for analysis, using the statistical program Statistical Package for Social Sciences (version 20.0).

The study complied with the formal requirements contained in the national and international regulatory standards for research involving human beings.

\section{Results}

The nine nurses participating in the study were 42.2 years old on average (standard deviation \pm 13.4 ), with an average time of primary care assistance of 8.2 years (standard deviation \pm 6.8 ). All participants were female. As for the professional qualification, six were specialists (three in family health, one in neonatology, one in public health and obstetrics, and one in management and auditing in health systems) and three participants had only undergraduate. Five participants affirmed that they used the Systematization of Nursing Assistance previously. Four nurses said they had used the nursing diagnoses during the nursing consultation. In total, the participants mentioned 42 nursing activities/interventions related to the delayed diagnosis in growth and development (Table 1).
Table 1 - Activities prescribed by nurses related to nursing diagnosis of delayed growth and development

\begin{tabular}{lc}
\hline Nursing activity & $\mathbf{n ( \% )}$ \\
\hline Forwarding to specialist professional & $23(54.7)$ \\
Talking with the child, encouraging to express your feelings & $11(26.2)$ \\
Encouragement through play, games, and music & $7(16.6)$ \\
Stimulating motor skills through exercises & $7(16.6)$ \\
$\begin{array}{l}\text { Encouraging the child to perform self-care activities (bathing, } \\
\text { dressing, shoe-shaping) }\end{array}$ & $7(16.6)$ \\
$\begin{array}{l}\text { Encouraging the child to interact with other children of the same } \\
\text { age group }\end{array}$ & $7(16.6)$ \\
Guiding parents about proper nutrition & $6(14.2)$ \\
Guiding parents to encourage children by age group & $5(11.9)$ \\
\hline
\end{tabular}

The activities mentioned only once by the nurses were: stimulating posture; helping the family in the care of the child; affectivity within the family; improvement in communication; improvement of child development and growth; stimulation of language; demonstrating approval of attitudes; setting clear and consistent limits; investigate exclusive breastfeeding; investigating vaccine scheme; carrying out childcare; avoiding isolation; assessing structural genetics of the child; stimulating the learning process; requesting exams; promoting autonomy; evaluating the evolution of neuromotor and linguistic development frameworks; encouraging the child to read; participating in puzzle, and building game.

Table 2 - Main activities prescribed by nurses for individuals with a nursing diagnosis delayed growth and development, according to the related defining characteristics

\begin{tabular}{|c|c|c|c|c|c|c|c|c|}
\hline \multirow{2}{*}{ Nursing activities } & \multicolumn{8}{|c|}{ Defining characteristics } \\
\hline & $\mathbf{A E}$ & ADH & CFA & D & DDH & IDA & IRA & TRD \\
\hline 1 Forwarding to specialist professional & 3 & 3 & 5 & 4 & 1 & 2 & 2 & 3 \\
\hline 2 Talking with the child, encouraging to express your feelings & 7 & - & - & 1 & 2 & 1 & - & - \\
\hline 3 Encouragement through play, games and music & - & - & - & 3 & 2 & - & - & 2 \\
\hline 4 Stimulating motor skills through exercises & - & 3 & 1 & - & 3 & - & - & - \\
\hline 5 Encouraging the child to perform self-care activities (bathing, dressing, shoe-shaping) & - & - & - & - & - & - & 7 & - \\
\hline 6 Encouraging the child to interact with other children of the same age group & 2 & 1 & - & - & 1 & 2 & - & 1 \\
\hline 7 Guiding parents about proper nutrition & - & - & 6 & - & - & - & - & - \\
\hline 8 Guiding parents to encourage children by age group & 2 & 2 & - & - & - & 1 & - & - \\
\hline 9 Stimulating physical activity practice & - & - & 3 & - & 1 & 1 & - & - \\
\hline
\end{tabular}


The main activities prescribed by nurses for children or adolescents with a diagnosis of delayed growth and development were related to the following defining characteristics: blunt affection; delay in performing skills typical of the age group; altered physical growth; inattention; difficulties in performing skills typical of the age group; inability to perform age-appropriate self-control activities; inability to perform age-appropriate self-care activities; reaction time decreased (Table 2).

Correspondence with the activities proposed by the NIC is observed among the main activities carried out by the nurses interviewed (Figure 1).

\begin{tabular}{|l|l|l|}
\hline $\mathbf{N o}$ & Activities proposed by the NIC & Activities developed by nurses \\
\hline 1 & $\begin{array}{l}\text { Building a trusting relationship } \\
\text { with the child }{ }^{1}\end{array}$ & $\begin{array}{l}\text { Talking with the child by encour- } \\
\text { aging her to express her feelings }\end{array}$ \\
\hline 2 & $\begin{array}{l}\text { Establishing a relationship be- } \\
\text { tween you and the child }{ }^{1}\end{array}$ & Talking and play with the child \\
\hline 3 & $\begin{array}{l}\text { Creating a supportive and } \\
\text { supportive relationship with } \\
\text { parents }\end{array}$ & $\begin{array}{l}\text { Helping of family members in } \\
\text { carrying out childcare }\end{array}$ \\
\hline 4 & $\begin{array}{l}\text { Offering appropriate vaccines }{ }^{3} \\
5\end{array}$ & $\begin{array}{l}\text { Promoting a healthy diet }{ }^{3} \\
\text { Investigating vaccination schedule }\end{array}$ \\
\hline 6 & $\begin{array}{l}\text { Teaching the importance of a bal- } \\
\text { anced diet, three meals a day and } \\
\text { nutritious snacks }{ }^{4}\end{array}$ & Guiding for proper nutrition \\
\hline 7 & $\begin{array}{l}\text { Reviewing nutritional require- } \\
\text { ments for specific age groups }{ }^{4}\end{array}$ & Guiding for proper nutrition \\
\hline
\end{tabular}

Figure 1 - Comparison of the main activities prescribed by primary care nurses, corresponding to the interventions recommended by the Classification of Nursing Interventions

Regarding the comparison of nursing activities, four NOC nursing interventions were selected, with a total of 134 listed activities. They are 1-improvement of child development, 2-care with development, 3-improvement of development: adolescent, 4- guidance to parents: educating children. For each nursing intervention described, there was an agreement of activities prescribed by the nurses. Thus, it was verified that 35 activities prescribed by nurses who work in the care of the child in the Primary Health Unit correspond to the interventions suggested by the NIC, such as the nursing activity "to offer toys or materials appropriate to the age" corresponds to stimulus through games, playing and music in the NIC.

Thus, the nursing intervention with the greatest number of correspondence was "improvement of child development." On the other hand, the "care for development" intervention had the lowest number of correspondence, with only one consistent activity with those prescribed by the nurses.

\section{Discussion}

The study presented the reduced number of participants as a limitation, as well as the low availability of publications within the scope of nursing taxonomies, a fact hindering to compare and verify results in new research. However, it was possible to know the practice of nurses in the promotion of the child health and the adolescent in the context of primary care and to verify if these actions are in harmony with the recommended by the NIC. Therefore, it is believed that the results of this study could foster the implementation of the nursing care systematization about the nursing diagnosis "growth retardation and development" and the respective nursing interventions and activities proposed by the NIC, enabling an improvement in the quality of care provided to patients.

In this regard, the study of nursing taxonomies becomes relevant, since it provides subsidies for the improvement of nursing actions and, consequently, for the improvement in the quality of health care for children and other people with some delay in growth and development. It is necessary to carry out and increase studies in the area, and the use of nursing classifications by professionals in their care.

Given the results of the study, 21 of the prescribed activities can be classified as direct care interventions for the child, for example, building a trust 
relationship with the child. Also, 14 as indirect care interventions, such as demonstrating the activities that promote the development to the caregivers, that is, activities directed to the parents/caregivers, but that bring benefits to the child care.

Most of the activities prescribed by the nurses were independent care, that is, they can be performed by the nurse without prescription from another professional, showing the autonomy that the professional has to implement actions in the problems related to child development. Among the prescribed activities, only two are identified as being collaborative, such as: monitoring the prescribed drug regimen, when appropriate; and ensure medical examinations and/or treatments are done at the right time, when appropriate.

The study observed a high number of prescribed activities that approaches the playful through playing and the interaction of children with each other. As they play, the child is appropriating their potentialities, building their world inwardly. Through playing, they learn to act; their curiosity is stimulated, they acquire initiative and self-confidence, providing their development. Therefore, playing is considered one of the most propitious means of knowledge construction, since it does not only contribute to cognitive and psychic development, but also to the motor, affective and social level ${ }^{(13)}$.

Regarding the level of correspondence between prescribed and postulated activities in Nursing interventions, a study ${ }^{(14)}$ that used the mapping of the actions prescribed by nurses in a pediatric hospital unit had 277 activities performed, and observed that most of them, 238 (86.5\%) corresponded to what is recommended by the NIC. In another research ${ }^{(15)}$, nursing activities were mapped for the ineffective respiratory pattern diagnosis, in which 125 nursing activities were prescribed, and all activities were shown to correspond to the recommended in the NIC. Thus it demonstrates the relationship between what is advocated in theory and what is done in clinical practice.

It is understood that the title and intervention proposed as activities by the nurses are different from the NIC taxonomy, since the Nursing Care Systematization has not been encouraged during the primary care consultations, but it is possible to see the presence of elements of this Systematization even in an incipient way. However, even if the title and intervention proposed by the nurses' activities are not identical to the NIC taxonomy, they advocate what it is established, for example, in direct interventions with the child.

The activities prescribed by nurses did not understand all the axes of child development since most of them were related to cognitive development. However, it can also be verified that in the NIC, there is a greater emphasis on care interventions aimed at cognitive development.

In any of these parameters, interventions can occur either individually (direct) or in partnership with parents and caregivers (indirect), ranging from the prescription of complementary exams to group orientations and health education, so parents and family feel responsible for the care of the child. In cases that require a more specific treatment, it is important to count on the participation of other professionals, intending to assist the child fully. Studies indicate that the stimulus to the child that presents some delay in development or patterns considered at risk should occur early since the chances of rehabilitation and recovery are more successful ${ }^{(16)}$.

The most prevalent nursing activity was entitled "forwarding to the specialist," evidencing the difficulty of the nurse in dealing with problems related to the development of the child. This corroborates a study in which only $7.8 \%$ nurses in the Family Health Strategy had general knowledge about child growth, and $64.4 \%$ were mistaken in a question about growth curve lines in the child's records ${ }^{(17)}$.

Another important factor to highlight is the difficulty of the nurse in understanding the growth and development phenomena, since there is no consensus in the literature about the concept, becoming an obstacle in the evaluation of child development in the 
context of primary care. The defining characteristics of inattention and incapacity to perform age-appropriate self-care activities were those that presented the least number of activities cited. However, the literature points out care related to the orientation on the hygiene of the child as one of the actions of the nurse, in the face of their degree of dependence ${ }^{(15-17)}$.

\section{Conclusion}

The activities prescribed by the nurses for this diagnosis do not meet all the axes of child growth and development if presented in a generic way. However, when compared to the activities recommended by the NIC, most of them were corresponding. Despite the clinical knowledge of the nurse, the identification of some indicators that presuppose the delay in the development of the child, is not based on the interventions of the NIC taxonomy of nursing, compromising the systematization of nursing care, generating specific interventions, directed to forwarding to other professionals, and at most guidance to parents and caregivers.

\section{Collaborations}

Silva EB and Monteiro FPM contributed in designing, analyzing and interpreting the data. Santos SS contributed to the writing of the article, critical review of the intellectual content and final approval of the version to be published. Joventino ES and Rouberte ESC contributed to the final approval of the version to be published.

\section{References}

1. Campos RMC, Ribeiro CA, Silva CV, Saparolli ECL. Nursing consultation in child care: the experience of nurses in the Family Health Strategy. Rev Esc Enferm USP. 2011; 45(3):566-74.
2. Fundação das Nações Unidas para a Infância. A situação mundial da infância. Crianças em um mundo urbano [Internet]. 2012 [citado 2017 jan. 13]. Disponível em http://www.unicef.pt/18/ Relatorio_SituacaoInfancia2012.pdf

3. Ministério da Saúde (BR). Saúde da criança: crescimento e desenvolvimento/Ministério da Saúde, Secretaria de Políticas de Saúde. Departamento de Atenção Básica. Brasília: Ministério da Saúde; 2002.

4. Costa L, Silva EF, Lorenzini E, Strapasson MR, Pruss ACSF, Bonilha ALL. Significado da consulta de enfermagem em puericultura: percepção de enfermeiras de estratégia saúde da família. Ciênc Cuid Saúde. 2012; 11(4):792-8.

5. Dantas AMN, Gomes GLL, Silva KL, Nóbrega MML. Nursing diagnoses for the stages of growth and development of children using ICNP®. Rev Eletr Enf [Internet]. 2016 [citado 2016 out. 25]; 18. Disponível em: http://dx.doi.org/10.5216/ree. v18.35524

6. Conselho Federal de Enfermagem. Resolução 358 de 15 de outubro de 2009: Dispõe sobre a Sistematização da Assistência de Enfermagem e a implementação do Processo de Enfermagem em ambientes, públicos ou privados, em que ocorre o cuidado profissional de Enfermagem, e dá outras providências. Brasília: COFEN; 2009.

7. Santos WN, Santos MAS, Lopes TRPS, Madeira MZA, Rocha FCV. Sistematização da Assistência de Enfermagem: o contexto histórico, o processo e obstáculos na implantação. J Manag Prim Health Care [Internet]. 2014 [cited 2016 Nov. 27]; 5(2):153-8. Available from: www.jmphc.com.br/ saude-publica/index.php/jmphc/article/v5n2/ pdf

8. Herdman TH. NANDA International nursing diagnoses: definitions and classification, 20122014. Oxford: Wiley-Blackwel; 2012.

9. Monteiro FPM, Araujo TL, Cavalcante TF, Leandro TA, Filho Sampaio SPC. Child growth: concept analysis. Texto Contexto Enferm [Internet]. 2016 [cited 2016 Nov. 29]; 25(2). Available from: http:// dx.doi.org/10.1590/0104-07072016003300014 
10. Bulechek GM, Butcher HK, Dochterman JM. Nursing interventions classification (NIC). St. Louis: Mosby; 2007.

11. Monteiro FPM, Silva VM, Lopes MVO, Araújo TL. Desobstrução ineficaz das vias aéreas: mapeamento das atividades de enfermagem para crianças com infecção respiratória. Rev Eletr Enf [Internet]. 2008 [citado 2016 out. 12]; 10(3):563-72. Disponível em: https://www.fen.ufg.br/fen_revista/v10/n3/v10n3a02.htm

12. Moorhead S, Delaney C. Mapping nursing intervention data into the nursing interventions classification (NIC): process and rules. Nurs Diagn. 1997; 8(4):137-44.

13. Falbo BCP, Andrade RD, Furtado MCC, Mello DF. Estímulo ao desenvolvimento infantil: produção do conhecimento em enfermagem. Rev Bras Enferm. 2012; 65(1):48-54.
14. Assis MN, Andrade ACR, Rogenski KE, Castilho V, Fugulin FMT. Nursing interventions in pediatric care: a contribution to measuring workload. Rev Esc Enferm USP. 2015; 49(2):83-9.

15. Nunes DP, Cavalcante AMRZ, Nunes PS, Mota, DDCF, Nakatani AYKV. Nursing intervention for inefficient breathing pattern diagnosis in the elderly. Rev Enferm UERJ. 2013; 21(6):754-9.

16. Ministério da Saúde (BR). Saúde da criança: crescimento e desenvolvimento. Departamento de Atenção Básica. Brasília: Ministério da Saúde; 2012.

17. Reichert APS, Almeida AB, Souza LC, Silva MEA, Collet N. Vigilância do crescimento infantil: conhecimento e prática de enfermeiros da atenção primária a saúde. Rev Rene. 2012; 13(1):114-26. 